\title{
Patterns of military rule and prospects for democracy in South Korea
}

\section{Abstract for chapter 8}

\section{Author: Yung Myung Kim}

In this chapter, the author attempts to clarify issues related to the characteristics of civil-military relations and democratic transition in South Korea, specifically the nature of the political system after independence, the internal characteristics of the military, the reasons for the eventual demise of military rule and the future prospects for democracy in Korea, and the military's role therein.

He examines the emergence of military rule and the changes in military rule during the Park Chung Hee and Chun Doo Hwan regimes.

He concludes with an overview of the prospects and conclusions of a nation moving towards a democratic polity with civilian control of the military.

\section{Keywords}

'Total Security System', authoritarian rule, bureaucratic authoritarian system, civil-military relations, personal control, quasi-civilian regime, Yushin system 


\section{8 \\ PATTERNS OF MILITARY RULE AND PROSPECTS FOR \\ DEMOCRACY IN SOUTH KOREA}

\section{Yung Myung Kim}

The role of the military in South Korean politics poses some interesting questions for the study of civil-military relations in developing societies. The military has dominated Korean politics for an unusually long period of time - nearly thirty years. On the other hand, recent trends towards democracy in Korea appear to be more deeply entrenched historically than in many other recently democratised polities, especially those in Latin America. This chapter attempts to clarify some more obvious issues related to these characteristics of civil-military relations and democratic transition in South Korea (hereafter Korea). Specific issues to be addressed include: the nature of the political system after independence which provided a structural framework for the military's political dominance; the internal characteristics of the military, reflecting and interacting with the overall political structure, which induced military officers to assume supreme power in Korean political economy; the reasons for the eventual demise of military rule and the beginning of civilian control of the military; and future prospects for democracy in Korea and the military's role in it.

Methodologically, a distinction may be drawn between structural and motivational factors in explaining the complex phenomenon of civil-military relations. The former help explain overall trends in civil-military relations; the latter are relevant to the more specific behavior of political actors. In this chapter, we will concentrate on structural factors, especially those affecting the balance of power between the military and civilian sectors, because our interest is in overall patterns of civil-military relations rather than specific political events.

\section{The Emergence of Military Rule}

There is no shortage of academic studies of the causes of military coups d'état which identify various factors at different levels of analysis - intra-military, 
societal, and international (Finer 1962; Huntington 1968; Janowitz 1964; Decalo 1976; Y.M. Kim 1985). However, the basic reason why the military not only intervenes in but dominates the politics of developing societies for considerable periods of time should be found primarily in the structure of relationships between the military and civilian sectors. Military rule in Korea illustrates clearly the almost inevitable consequence of unbalanced power relations between the military and civilian sectors following the creation of a newly independent state; with the division of the Korean Peninsula, the military was developed disproportionately to the civilian sectors.

It should thus be noted at the outset that the military was overdeveloped compared to any other sector in Korea at the time of the coup of 16 May 1961. The Korean military started as the Korean Constabulary, established by the American military government (1945-1948) for the purpose of maintaining domestic stability mainly against agitation by leftist groups. The military gained increased sociopolitical importance because of the division of the nation during the Occupation period. The Korean War (1950-1953) provided an important background to the military's dominance of Korean politics, although its intervention in politics did not take place until several years after the end of the war. A major reason for this was the time-lag between the creation of the Republic and the military on the one hand and the politicisation of military officers on the other. As a result of the war, the size of the military grew to a spectacular extent (from 100000 in 1950 to 700000 in 1956, although it was reduced by 100000 in 1957), but its institutional, technological, and organisational development was even more significant. Assisted by massive US aid, the military developed into the most modernised and Westernised sector in Korea during the 1950s. The civilian sectors, especially universities and the bureaucracy, were also experiencing modernisation, but they were less organised and less modern in outlook, smaller in size, and limited in political and economic participation (Lee 1968:150). Later, with rapid industrialisation, the civilian sectors modernised more rapidly than the military, but reversing the military's political dominance, once it had taken root, proved complicated and time-consuming, as was tragically manifested in the Kwangju Uprising of 1980.

At a societal level, the political situation created the structural conditions for long-term military rule in Korea: the Republic was founded upon an imported ideology of liberal democracy, but Korea's political tradition lacked experience of this Western system; as a result, liberal democracy quickly degenerated into the authoritarianism of Rhee Syngman's 1948-1960 patrimonial rule. The effort of the succeeding Chang Myon government to re-establish a democratic system was bound to fail because its leadership could not control the political 
turbulence created by the April Uprising of 1960 which toppled the Rhee regime. Imposing liberal democracy upon an unprepared nation simply did not work. What it did was to provide the basis for the emergence of military rule, initiated by younger officers who denied the idea of liberal democracy entirely and instead sought single-mindedly the objectives of economic growth and effective leadership. The coup which took place on 16 May 1961 cannot be fully understood without considering the coup leaders' motivations, which stemmed from the political discontent over the lack of opportunities for promotion and specific political circumstances created after the April Uprising. However, even if those conditions had not occurred, it seems likely that the Korean military would have taken a major role in politics at some time.

In a sense, the coup of 1961 proved to be an historical turning point which temporarily put an end to political struggles amongst the diverse forces which sought to fulfil different objectives of 'nation building' in the newly independent country. In this struggle, the military's alternative - capitalist industrialisation combined with authoritarian control - gained supremacy and dominated Korean society for some time.

\section{Changes in Military Rule: The Park Chung Hee and Chun Doo Hwan Regimes}

After the 1961 coup, officers governed South Korea for two years under the Supreme Council for National Reconstruction. They eventually turned the system into a kind of quasi-civilian one, providing party politics in which coup-leadersturned-civilians occupied supreme positions. But this quasi-civilianised party politics became increasingly a device for Park's personal accumulation of power. The personalisation of power came to define the characteristics of Korean military rule in the 1960s, culminating in the promulgation of the Yushin Constitution in October 1972.

Why did Korea's military rule turn out to be quasi-civilian and personal, rather than direct and institutional, as was the case with its Latin American counterparts? Answers are to be found in the internal characteristics of the Korean military at the time of the coup: the Korean military was not sufficiently institutionalised to put its political domination on a formal basis; the coup was executed by factions centred on the eighth class of the Korean Military Academy, and the infighting among the coup leaders was substantial (S.J. Kim 1971:112-118; Lovell 1975:183-188). Factional disputes during the years of direct rule were essentially struggles for more power sharing, but they also reflected different conceptions of the coup leaders' role in politics. At the time of the coup, the officers, although 
having to a considerable degree a ruler mentality, did not have a clear ideology or set of policy programs to implement after seizing power. In other words, they had not yet developed the kind of 'new professionalism' which Latin American officers developed from the late 1950s (Stepan 1973); all they possessed was unequivocal anti-communism and vague conceptions of reform, intra-military and societal. The younger officers who planned and executed the coup were more of a 'ruler' type (Nordlinger 1977: 26-27) and, thus, intended to stay in power indefinitely. Senior officers, who were involved at later stages of the coup, were 'moderators' (ibid.: 22-24) who wanted to return to the barracks after 'cleaning' the polity. Because of internal struggles among coup leaders, the regime's characteristics turned out to be eclectic; it was, after a considerable period of direct military rule, a quasi-civilian regime.

Quasi-civilianisation and factionalism provided the conditions for Park's accumulation of personal power. Quasi-civilianisation came with the inauguration of Park Chung Hee as president after his narrow electoral victory against Yun Po Sun, former symbolic president in the Chang administration. It generated party politics around the ruling Democratic Republican Party and divided opposition parties, which merged in 1967 to form the New Democratic Party. Over a long period, however, party politics became a device for prolonging and concentrating the president's political power. The political role of parties decreased and the everstrengthening bureaucracy and security forces took over their role.

The weakening of party politics and strengthening of the bureaucracy was directly related to the concentration of power in the hands of the president. Park lacked Rhee's personal charisma and failed to consolidate his power base from the outset. But he possessed the rare capacity to tilt the power balance toward himself in entanglements within the ruling group. He removed the possibility of revolt from within the military and utilised party politics for his own ends. After seizing supreme power, he removed any possibility of an independent power base being formed by using his classic tactics of 'divide and rule' within the military and the party (S.J. Kim 1971).

A turning point in Park's consolidation of personal power came with the constitutional revision of 1969, which was executed despite considerable resistance, not only from opposition politicians and students/intellectuals (who represented the political opposition at the time) but also from within the ruling group, especially from Kim Jong Pil. The constitutional revision allowed Park a third term as president and signalled much more systematic and formidable institutional arrangements aimed at giving Park indefinite control of power - the proclamation of the Yushin system. With this, the façade of party politics introduced after the 1961 coup virtually disappeared and Park's life-time authoritarian rule was 
guaranteed. Authoritarian control was strengthened and power became highly personalised. Park justified the authoritarianism by emphasising administrative efficiency which he deemed indispensable for reunification and economic growth.

Competing explanations have been given for the emergence of the Yushin system, which was similar to the bureaucratic authoritarian system in Latin America (Kang 1983; Im 1987; Y.M. Kim 1986). Clearly, however, it represented a culmination of the personalisation of power which developed after the inauguration of Park. With the advent of the Yushin system, a military-authoritarian regime changed into a more personalised authoritarian one. This change required massive political repression of civil society and of elite politicians. In order to maintain political control, as well as using outright repression, the president employed the 'ideology of security', referring to the threat of North Korea. Personal control, combined with quasi-military-mobilisation, made possible his (and the military's) long-term domination of Korean society, a condition which was absent in most other developing countries.

The Yushin system eventually collapsed with the assassination of Park Chung Hee by one of his close associates, Kim Jae Kyu, the chief of the Korean Central Intelligence Agency (another institutional device created for quasi-civilian rule). Yet, the demise of the personal ruler did not result in the demise of military rule; rather, another military group, often called the New Military Group, occupied the power vacuum created by Park's death. To understand why this happened we should first look into the causes of the breakdown of the Yushin system.

The Yushin system resembled the bureaucratic authoritarian (BA) system in Latin America, but its power base was more personal than the latter. At the same time, it shared characteristics with the pre-war militarist system of Japan, in that the state systematically employed the security threat, real or perceived, as a means of mobilising and controlling civil society.

The 'Total Security System', the term coined by the military regime, was another aspect which distinguished the Yushin system from the Latin American BA regimes. The regime's rationale for the proclamation of the Yushin system was in terms of national security and economic growth, as well as the administrative efficiency deemed indispensable to accomplishing the first two objectives. During the Yushin years, from 1972 to 1979, the whole country was systematically organised into a kind of garrison state, which ultimately contributed to strengthening the authoritarian ruler's political power. It is true the Korean peninsula was at the time on military alert, and many Koreans shared the government's threat perception in the mid 1970s when a large part of the Indochina peninsula was under communist control. This not only facilitated the state's control over the society, but effectively weakened the opposition (Sohn 1989:82-83). 
Combining personalisation of political power and militarisation of the society, Park Chung Hee stifled any semblance of liberal democracy, the façade of which was created after the 1961 coup. He denounced the 'Western system of democracy' as inappropriate to Korea's 'emergency' situation and instead presented 'Korean-style democracy' which emphasised efficiency and national harmony under a great leader (Park 1978). Needless to say, the Korean-style democracy was an antithesis of genuine democracy, and was directed toward perpetuation of Park's personal power.

However, this coercive system could not be imposed upon civil society indefinitely. In addition to the general problems of BA regimes, such as the inefficacy of coercion as a basis for long-term political control, and the breakdown of the ruling coalition in the midst of political-economic crisis (O'Donnell 1979), personalisation of power produced a political problem more salient than in more institutionalised Latin American BA regimes, namely the problem of political succession. Because the consolidation of personal power prevented the regime from preparing for post-Park transition, Park's political options were much too limited when popular revolt erupted in 1979; he could not find an effective political successor who would maintain the existing political and economic structures while easing the pressures of popular discontent. The regime was unable to respond effectively to growing political challenges from the combined forces of students, intellectuals, workers, and opposition politicians. The situation was further aggravated by personal animosities between close associates of the president, his chief body guard, Cha Ji Chul, and Kim Jae Kyu, his assassin. It was aggravated by a dispute about which option to take to resolve the political crisis. The hardliner Cha's option of brutal suppression was gaining presidential approval when both of them were murdered by Kim, who was considered the moderate.

Despite the passing of personal rule, the basic structures of the polity, the society, and the economy remained the same; if there was any change, it was toward a deepening of the existing system, although there were naturally changes in political recruitment. The basic reason for this was that Park's death and the breakdown of the Yushin system did not come about by popular uprising but from within the power bloc. What was toppled was an individual ruler, and not the system itself. This was mainly because the opposition forces lacked sufficient power resources to use the death of the ruler to change the regime. The Yushin system had become outdated and was losing its dynamism, but the socio-political and, above all, military structures which defined the system remained intact. In a way, it proved the resilience of the Korean style 'Total Security System'.

After brutal struggles between military-authoritarian and civilian-democratic forces during 1979-1980, the eventual victor turned out to be the New Military 
Group centreed around Chun Doo Hwan and Roh Tae Woo, who were to become the next two presidents. What was this group? During his one-man rule, Park Chung Hee, while firmly controlling the military with a combination of 'stick and carrot', had allowed a selective group of senior officers to accumulate power as long as they were loyal to him. This politicised a segment of the officer corps and provided them with a basis for resuming power after Park's assassination by the military. The locus of power resided in a group named Hanahoe, of which both Chun Doo Hwan and Roh Tae Woo were leading members. Members of the group were graduates of the Korean Military Academy and were from North Kyongsang Province. It was supposed to be an informal fraternity society but, under tacit permission of the president, it accumulated political power and finally emerged as the most powerful group after Park's death.

Officers' ideological orientations were also undergoing change during Park's rule. Within the military there emerged growing interest in non-military political and social issues. Through curriculum changes in the institutions of higher military education, such as the National Defence College, military officers systematically studied political and social issues (J.H. Kim 1978). For them, the concept of national security should be expanded to include defence against internal enemies such as communist agitators. Although the officers' major concerns lay still in the area of national defence against possible invasion from North Korea, they were developing aspects of the 'new professionalism' found in their Latin American counterparts. As a result, they strengthened and systemised a ruler mentality which provided an ideological basis for reintervention in politics.

Compared to the military's ideological, organisational, and physical strength, democratic forces lacked the organisational cohesion necessary to force the military to remain in the barracks. Students, workers, and intellectuals were incapable of accomplishing what they wanted, namely political democratisation and a more equitable distribution of wealth, because they lacked organisation and effective leadership. Added to this was the division in the leadership of the opposition party between Kim Dae Jung and Kim Young Sam. Power imbalance between the military and democratic forces was further widened by the withdrawal of support for the democratic movement by the middle class, which had more interest in political stability and economic growth than in democratisation. As a result, the breakdown of the Yushin system did not develop into more than a violent transfer of power from one authoritarian regime to another. The Chun regime retained essential characteristics of the Yushin regime, though there were also significant differences between the two.

While the 1961 coup was accepted by the general populace as an almost inevitable result of political crisis, Chun's seizure of power was simply not accepted 
by everyone in Korea, for reasons discussed below. The immense political cost of Chun's rule was manifested in the bloodshed in Kwangju. He tried to compensate for weak political support by coercion (and lip service to social reform). Thus, the degree of political repression was considerably higher after his assumption of power than immediately after the 1961 coup (although somewhat lower than under the Yushin system).

However, Chun's coercive rule was met by strengthened opposition, which grew in size and was better organised and ideologically radicalised. This was an inevitable consequence of social diversification and a long history of political opposition but, more directly, a result of the brutal suppression of the democratic movement in Kwangju and of growing anti-Americanism derived from the alleged role of the US there. Consequently, democratic challenges to the Chun regime grew much stronger than those to the Park regime.

Regime characteristics were also different. Park Chung Hee consolidated personal control over the state apparatus and political society which Chun could not emulate. Chun, for his part, accumulated some degree of personal power over the ruling bloc, but the possibility of his long-term rule was effectively blocked from the very beginning because he argued that a single term president presented possibly the only source of political legitimacy. In addition, the institutional development of the military by then rendered one-man rule extremely difficult. As a result, soon after Chun's inauguration the issue of political succession became prominent within both the ruling and opposition camps.

Although Chun's control of the military was relatively firm, it cannot be said that he established personal control over it. Rather, the New Military Group constituted a collective leadership around the senior leader, Chun, again reflecting the military's institutional development as compared to 1961. Although it could not, either, be regarded as an institutional military regime, in which the military's institutional norms and procedures dominated the regime structure, the Chun regime certainly possessed some of the characteristics of such a regime. This fact was significant in the transition from Chun's rule; Chun's fall did not require the sort of violence which was necessary in the transition from Rhee and Park because under his rule power was not entrenched exclusively in a personal dictator. Especially toward the end of Chun's rule power was more or less divided among the ruling group, and internal friction within the ruling group played a significant role in determining the direction of political transition.

The most significant difference between the two regimes probably lay in the historical functions each was bound to perform. While Park's regime, for all its contradictions, played positive roles in economic development and political stability at an earlier stage of nation building, Chun's rule was essentially redundant 
in that the historical function of military-authoritarian rule had virtually evaporated. Chun tried to reverse the historical flow toward a more open political and economic system and, in so doing, paid the price with the lives of hundreds of citizens. As a result, the Chun regime lost its political legitimacy. This was not compensated for by government's efficacy in policy implementation; in fact, a powerful democratic movement erupted in spite of the economic boom in the latter half of Chun's term. Lack of political legitimacy produced constant and severe opposition during Chun's rule.

\section{Democratisation and the End to Military Rule?}

With the inauguration of Roh Tae Woo as president in 1988, Korean politics appear to have entered a new era of democratic transition. This transition is not just a result of the transfer of power from Chun to Roh but a consequence of long-term structural changes in the relationship between the military and civilian sectors.

During the course of almost thirty years of military rule, the Korean economy and society were fundamentally transformed; society became diversified, class forces grew and became better organised, and the democratic orientation of the general populace strengthened. With these changes, the military was no longer the most advanced sector of Korean society. Structural changes were already evident when a massive struggle erupted between the military and civilian forces in 1980, but the New Military Group appears not to have been aware of this change, believing that it could still lead and dominate Korean society. The year 1987 was different from 1980; Chun's term was about to terminate, although rumors lingered that he would seek to stay in power. The remaining problem was how to reorganise the political structure for the post-Chun period. Harsh authoritarian rule was out of the question from the beginning; the democratic movement had strengthened, and the military certainly wished to avoid brutal struggles such as the Kwangju Uprising.

The result was a combination of democratic pressures from the opposition camp (basically the same members as in 1980, but better organised and far more radicalised) and the political tactics of the ruling group, which made for limited democratisation. Democratic forces issued a powerful challenge but the ruling group did not employ the armed forces to put down the challenge, because senior officers as well as the president were not willing to risk such action and the US government was putting pressure on the regime for a peaceful transition of power. Roh Tae Woo, representing a moderate faction of the ruling party, used the situation to turn the tide toward his group. Roh proclaimed that he would agree to presidential elections, which the opposition had long demanded, and promised 
the release of Kim Dae Jung and other opposition leaders. (It was recently revealed that this political concession was initiated by Chun rather than Roh. See S.I. Kim 1992.) As a result, the struggle for democratic transition moved from the streets to the political parties. In subsequent presidential elections the opposition was once again hopelessly divided between archrivals Kim Young Sam and Kim Dae Jung. In a factionalised contest Roh earned electoral victory with only 36.6 per cent of total votes. His victory was only possible because of the division of the opposition and, thus, his political legitimacy was shallow from the beginning.

Democratisation in Korea displays some features unique among recently democratised countries. Most obviously, while in other countries the ruling party lost power for a variety of reasons, in Korea it retains power as democratisation was achieved by one faction, a moderate faction, of the ruling group.

How, then, can the ruling bloc still hold power in Korea despite massive challenges from the majority of the electorate, and why does the Roh government try to convince people that it represents their democratic wishes? The answer to the first question can be found in the weakness of the opposition. Even when the military is willing to give up power, its withdrawal from politics cannot be completed unless there are political institutions, notably political parties, capable of assuming power (Finer 1985:75-76). In Korea, the opposition party has lacked this capacity mainly because it has been divided into two intransigent rival camps. In the case of the second question the answer lies in what was discussed previously, the evaporation of historical functions of authoritarian rule. Roh Tae Woo appears to understand that it is now impossible for any group in Korea to continue authoritarian rule. He tries to consolidate political support with plans for democratic reform, although it is hard to initiate because the veto power of entrenched interests, including the president's own, is still very strong. The passing of authoritarian rule, combined with lack of alternative democratic leadership, ultimately led the process of political transition in Korea into a kind of compromise (a compromise by default), a limited democratisation initiated by opposition forces but soon taken over by the existing power bloc.

After inauguration, Roh consolidated his grip on the military by a series of changes in key positions. Officers' political attitudes also seem to have been changing. There were instances of discontent about decreased political status among officers, inevitable in the democratisation process; but they were overcome and the president's control of the military now seems to be stable enough. Korean officers appear to understand that another intervention in politics would be futile. They vividly remember what happened to Chun's brutal takeover of power and, more fundamentally, they perceive irreversible changes in the relationship between the military and the civilian sectors. 
Within the military itself there also seems to be less inclination towards political intervention; disharmony between age and rank, premature promotions, and factional struggles, which were the essential causes of the officers' political discontent, seem to have virtually disappeared (Hong 1990:136-138). Officers still find some sources of discontent, such as narrow opportunities for promotion, but this is not likely to lead to direct intervention in politics.

However, while the structural conditions which would facilitate military rule have now disappeared and officers' motives for direct political action have also significantly diminished, it is still doubtful whether the democratic polity in Korea is securely institutionalised.

To be able to answer this we need to understand exactly what are the characteristics of the Roh regime. Roh Tae Woo was clearly a leading member of the New Military Group which staged the coup against the formal military authority, and brutally suppressed people demanding democracy. The military is still a powerful force in Korean society; it wields strong influence in Korean politics and ex-officers still dominate key areas of politics and society. It is thus difficult to consider the Roh government genuinely civilian. But, on the other hand, it can scarcely be described as a military regime (even a quasi-civilian military regime) either, because it does not depend primarily on the physical force of the military for its political control. Politics in Korea is now managed through a kind of civilian-led liberal democratic procedure in which elections and public opinion are significant. Seen in this light, the present regime stands somewhere between military-authoritarian and civilian-democratic (and hopefully developing from the former to the latter).

\section{Prospects and Conclusions: Toward a Democratic Polity with Civilian Control of the Military?}

As has already been argued, the basic reason for the unusually long term of military rule in South Korea lies in an unusually spectacular gap in power resources between civilian forces and the military. Overdeveloped state apparatus, including the military as well as police and bureaucracy, consolidated a preemptive control over the underdeveloped civil society. This phenomenon is not uncommon in post-colonial societies (Alavi 1979), but it was especially evident in Korea because the South has been in constant military tension with the North, and the military has thus occupied a more critical position than in other postcolonial societies.

Nevertheless, it is paradoxical that once the democratisation process began, the chances for the military's reintervention in politics appear to have become 
more remote in Korea than in, say, Latin America, where the military was forced out of political power but society is still conflict-ridden. Certainly, since Roh's inauguration, Korean politics is in disarray with factional struggles and unfulfilled democratic dreams, while the economy is also in considerable difficulties with a growing trade imbalance, inflation, and class conflicts. Yet, these issues do not appear likely to bring the military back into politics in the foreseeable future. The structure of the relationship between the military and civilian sectors has been reversed; now the military is underdeveloped in comparison to the civilian sectors, and political power will never again be derived primarily from naked physical force.

In this regard, the Korean cycle of authoritarianism and democracy appears to be longer than in most developing countries (though resembling Spain and Portugal where democracy is more or less consolidated after long periods of dictatorship by personal rulers). Korea now seems to have entered the first stage of democratisation after a long period of authoritarian rule. But whether democracy will be institutionalised and civilian control of the military consolidated in the short run is another question; short-term reversals of events (which may be derived from conjunctural and motivational factors) are always possiblities in a long-term cycle (which is determined by structural factors).

For the foreseeable future, Korean politics will demonstrate democratic tendencies, with a clear limit to the participation of diverse interests (especially those of the have-nots) in the political process. Limited democratisation may well be a worse alternative, because it will incite discontent among radical and reactionary forces at the same time. What is important in this situation is effective political leadership to control demands by the diverse forces to a degree acceptable for the maintenance of the nascent civilian political structure, and at the same time pursue democratic reform and more equitable social transformation. When political leadership lacks this capacity, the military, and other discontented forces as well, will impose political pressure in one way or another, even if an outright coup is not plausible.

Civilian control of the military, a minimum requirement of consolidation of democracy, depends upon the internalisation of 'democratic professionalism' among officers, according to which the military accepts 'not only the political subordination of the armed forces to the democratically determined will of the nation, but also their professional subordination to constitutionally designated state authorities' (Fitch 1989:134). It is too early to determine whether Korean military officers have internalised democratic professionalism. Political orientations of Korean officers are hard to clarify because there are deficiencies in empirical analysis, but the opinions and actions of several senior officers during 
democratic transition showed that they still retained the essential features of the new professionalism. It would be unreasonable to expect that Korean military officers will abandon this political attitude in the short term. Their political attitudes are rapidly changing, but this change was imposed upon them by democratic transition. To achieve a more positive acceptance of democratic civilian authority by the military, changes must occur not only in officers' political orientations but also in political institutions and overall social structure as well. 